\title{
A STUDY OF ATMOSPHERIC DEPOSITION ONTO THE SNOWPACK IN NORTHERN SASKATCHEWAN
}

by

\author{
S..R. Shewchuk
}

(Saskatchewan Research Council, 30 Campus Drive, Saskatoon, Saskatchewan S7N 0X1, Canada)

\begin{abstract}
The purpose of this study is to use the snowpack of the Saskatchewan portion of the Precambrian Shield as a passive collector of atmospheric total deposition. Although the focus is on the anions of sulphate and nitrate, the hydrogen ion and various metals are also considered.

Twenty-six small lakes on the Precambrian Shield area of northern Saskatchewan were used as sites. The lakes were all approximately 1 square $\mathrm{km}$ in area and serviced by aircraft. The study was conducted in late March 1982 and 1983 just before the major snowmelt period.

Concentrations of sulphate ranged from 0.26 to 7.3 $\mathrm{mg}^{-1}$. The concentrations were typical of large areas in northern Saskatchewan with sharp transitions in composition occurring as the treeline boundary was encountered. Typical sulphate deposition was approximately $30 \mathrm{mg} \mathrm{m}^{-2}$ in the Precambrian areas and $150 \mathrm{mg} \mathrm{m}^{-2}$ in the other areas. The distribution of conductivity in the snow cores ranged from 6 to $13 \mu \mathrm{S}$ $\mathrm{cm}^{-1}$. Most of the snow on the Precambrian Shield areas can be described as acidic, with $\mathrm{pH}$ values of the meltwater being below 5.6 .

Metals such as $\mathrm{Ca}, \mathrm{Mn}, \mathrm{Mg}, \mathrm{Zn}$ and $\mathrm{As}$ were measured across the region. The metals $\mathrm{Ca}$ and $\mathrm{Mg}$ show a direct correlation with high sulphate levels south of the treeline. Metals such as $\mathrm{Zn}$ and $\mathrm{As}$ show anthropogenic influence particularly within $100 \mathrm{~km}$ of industrial sources. Large areas of the study region show uniform and low deposition to the snowpack. It is suggested that natural atmospheric processes are dominating deposition in this area of Canada.
\end{abstract}

\section{INTRODUCTION}

The purpose of this study was to use the snowpack of northern Saskatchewan as a passive collector to determine the extent of anthropogenic deposition to the various ecosystems. Over northern Saskatchewan a large portion of the yearly precipitation falls as snow. Provided air temperatures are below freezing, snow surfaces trap gases and particulates (Elgmork and others 1973, Barrie 1980). During a winter with little or no snowmelt most of the pollutant load is retained in the snowpack. According to Johannessen and Henriksen (1978), from 50 to $80 \%$ of the pollutant is released in the first $30 \%$ of meltwater.

Shewchuk (1979) has shown that trace levels of sulphur dioxide are entering the Precambrian region of Saskatchewan on an episodic basis. It is quite likely that this sulphur dioxide is influencing acid deposition in this area.

Snow surveys were conducted on a series of small lakes in northern Saskatchewan during late March in the years 1982 and 1983. The study area, within western Canada, is shown in Figure 1. Twenty-six small lakes were selected to cover this study area uniformly, representing approximately $4.6 \times 10^{5} \mathrm{~km}^{2}$. The area is composed of granitic and quartzite sandstone bedrock and is largely devoid of carbonate. On the Precambrian Shield, there are many freshwater lakes; these have been
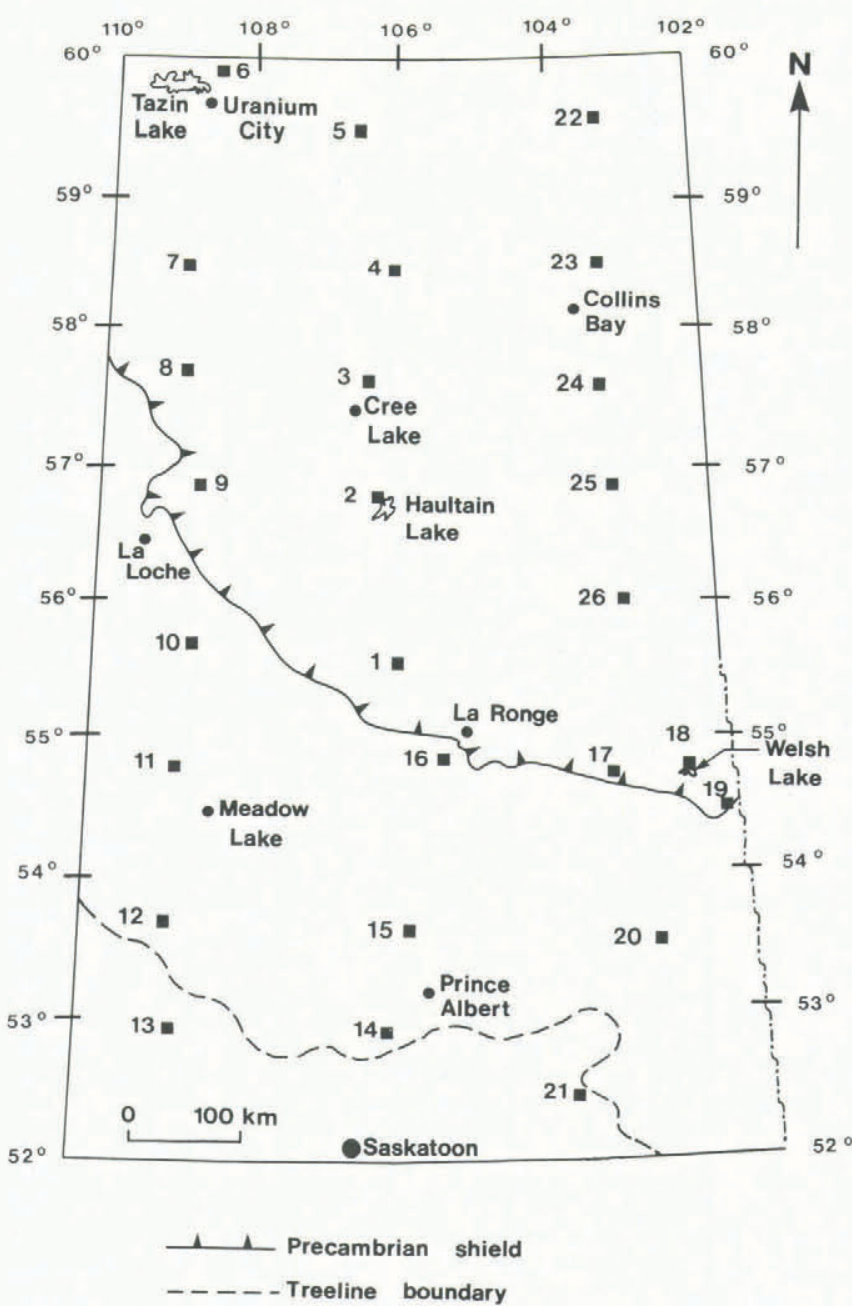

Fig.1. Snow survey site locations within the study area.

classified as being highly sensitive to acid deposition (Shewchuk 1982).

There are many large point source emitters within $100 \mathrm{~km}$ of the boundary of the study area. At present they account for in excess of 346000 tonnes $a^{-1}$ of sulphur dioxide emission (Canada. Minister of Supply and Services 1981). Part of this emission originates from a metal smelter at Flin Flon, Manitoba (212000 tonnes $\mathrm{a}^{-1}$ ) while the oil sands industry located near Fort McMurray, Alberta contributes much of the rest (134000 tonnes $\left.\mathrm{a}^{-1}\right)$. Significant increases in output of emissions of sulphur oxides is expected in the next several decades (Webber and Warne 1979). The oil sands area is located predominantly upwind of the highly sensitive Precambrian Shield (Hopkinson and Dublin 1981) of Saskatchewan. 


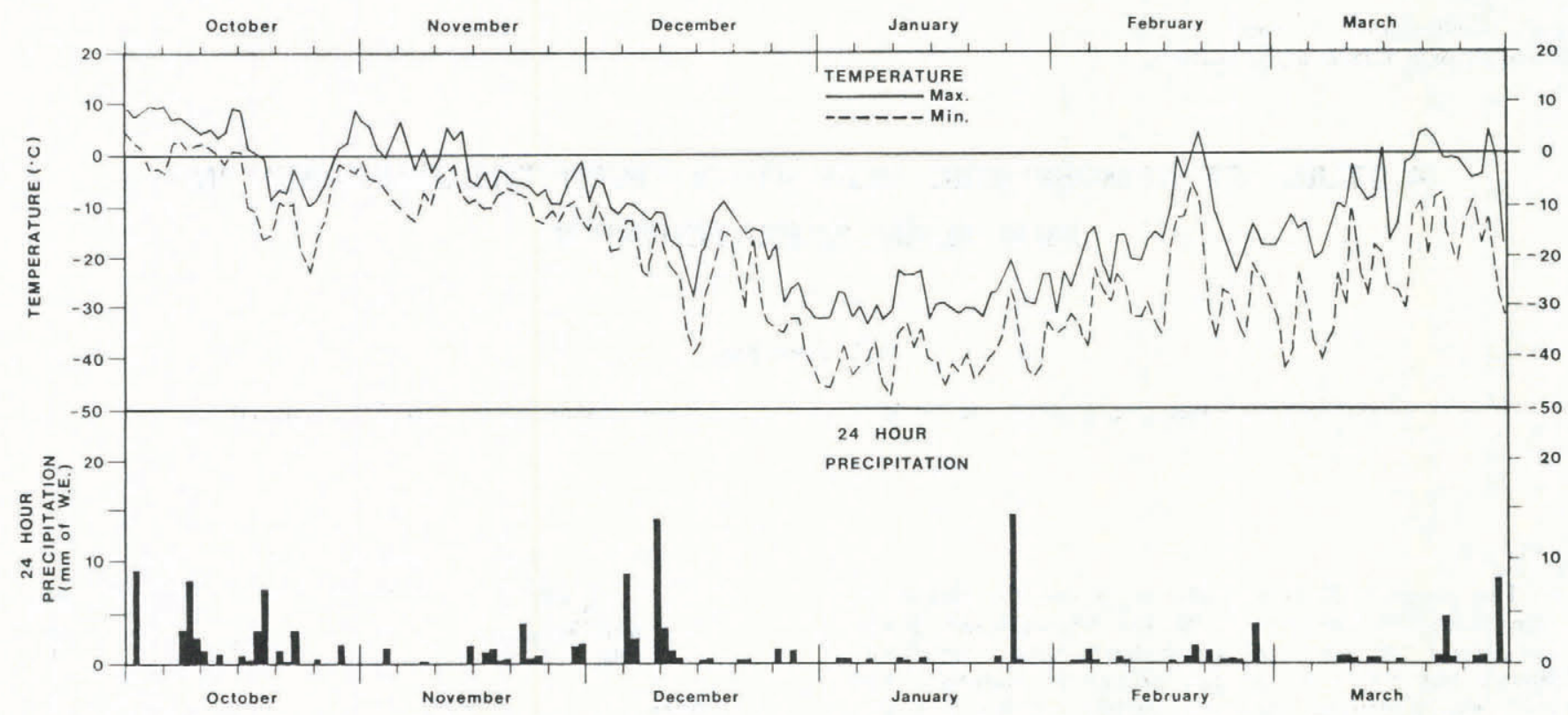

Fig.2. Maximum-minimum daily temperatures and $24 \mathrm{~h}$ precipitation for Cree Lake, Saskatchewan,

October 1981 to March 1982. (Data from Environment Canada.)

\section{PROCEDURES}

The twenty-six lake sites were reached by a ski-equipped Cessna 185 aircraft. Lakes selected for this study had to be approximately $1 \mathrm{~km}^{2}$ in area and be representative of the region in which they were located. The small lake allowed for convenient access and minimized the effect of snow drifting off the lake surface. Nearly all these sites were remote and only accessible by aircraft.

Normally the centre of the lake surface proved to be the best location from which snow cores could be taken. Snow cores were taken with acrylic tubes $1.5 \mathrm{~m}$ in length with diameters of 10 and $15 \mathrm{~cm}$, two sizes being used so that the snow volume could be controlled (i.e., for deep snow the smaller diameter would be used and for shallow snow the larger diameter would be used). Normally the corer was inserted vertically into a clean, smooth area of snow. It was pushed through the snowpack to the surface of the lake ice. It was then dug out with a plastic shovel. The texture of the ice surface was noted carefully and if any slush or melting was detected the snow core was terminated just above the slushy area. It was important to avoid the collection of surface lake slush and water because it is the chemistry of the snowpack that is the subject of this study and not the chemistry of a snow-water interface. The presence of meltwater on the ice surface below the snowpack was rare. The ice surface at the base of the snowpack was unusually hard, smooth ice. The chemical composition of the total core was of interest. However, if major melt periods identified as layering in the snow were observed the separate layers were collected individually.

The samples were transported to the laboratory in the frozen state. They were kept frozen up until the time of chemical analysis. The snow was allowed to melt and as soon as room temperature was reached the sample was analyzed. Generally sample analysis was completed on the same day. Sulphate was determined in the melted sample by ion chromatography. Nitrate was determined by cadmium reduction, and $\mathrm{pH}$ was determined both by electrode techniques and Gran (1952) titration procedures. With the exception of arsenic, metals were determined by inductively coupled plasma emission spectroscopy. Arsenic was determined. by hydride generation.

For most lake surfaces three snow cores were analyzed for all constituents. At one location detailed deposition studies were carried out on land snow cores as well as lake snow cores in an attempt to assess the effect of drifting.

\section{RESULTS}

Winter in this area is an ideal time for the determination of the extent of anthropogenic deposition on to the snowpack by means of snow chemistry studies. The maximum-minimum temperature structure and the $24 \mathrm{~h}$ precipitation at Cree Lake is shown in Figure 2. Cree Lake is located centrally in the region. The air temperature is consistently below $0{ }^{\circ} \mathrm{C}$ from about mid-November, and little melting occurs until mid-March. It is therefore reasonable to assume that most of the chemical deposition arriving on the snow surface remains essentially within the snowpack during the period from mid-November to mid-March.

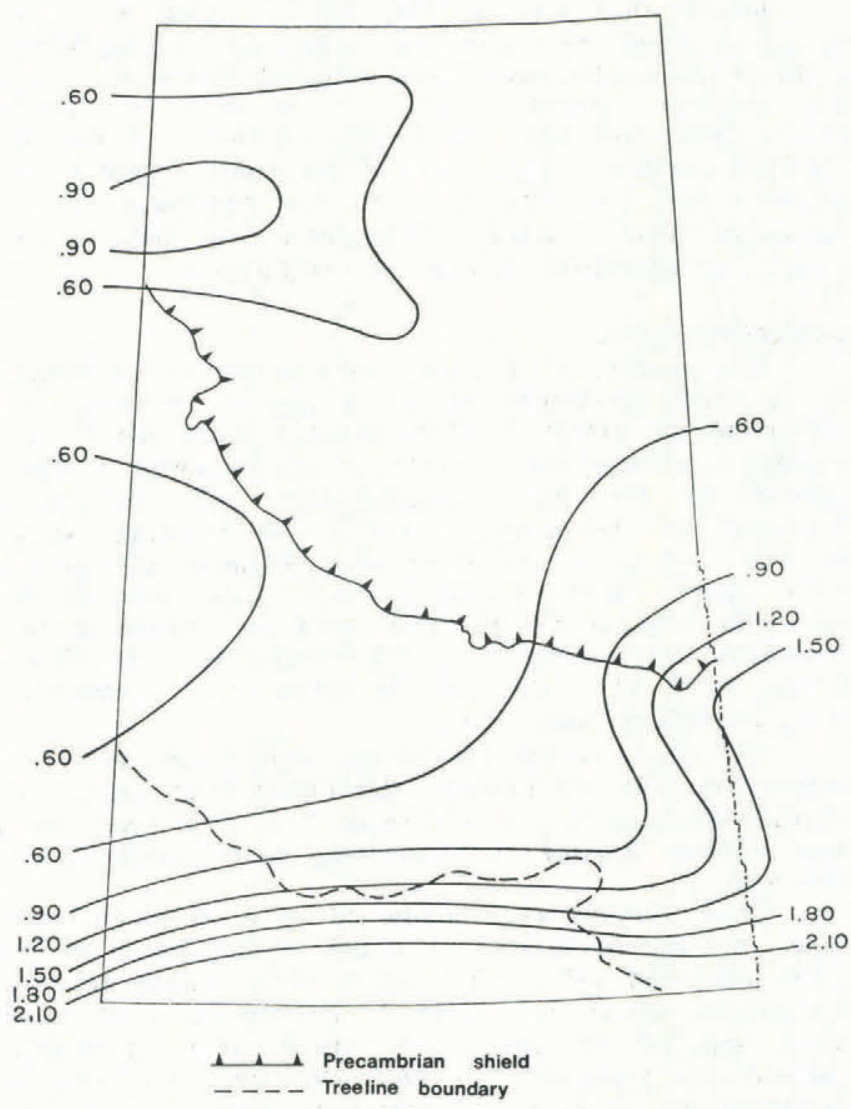

Fig.3. Sulphate concentration (mg $\left.1^{-1}\right)$ in snowmelt water collected in March 1982. 
TABLE I. CONCENTRATION IN THE SNOW OF VARIOUS IONS AT TAZIN LAKE, HAULTAIN LAKE, AND WELSH LAKE

\begin{tabular}{|c|c|c|c|c|}
\hline $\mathrm{Ca}$ & $\left(\mathrm{mg} \mathrm{l}^{-1}\right)$ & 0.16 & $<0.05$ & 1.0 \\
\hline $\mathrm{C} 1$ & $\left(\mathrm{mg} \mathrm{1^{-1 }}\right)$ & 0.03 & 0.01 & 0.066 \\
\hline $\mathrm{HCO}_{3}$ & $\left(\mathrm{mg} \mathrm{1^{-1 }}\right)$ & 0.6 & $<0.5$ & 3.9 \\
\hline K & $\left(\mathrm{mg} \mathrm{l}^{-1}\right)$ & $<0.1$ & $<0.1$ & 0.2 \\
\hline $\mathrm{Mg}$ & $\left(\mathrm{mg} \mathrm{l}^{-1}\right)$ & 0.01 & 0.02 & 0.48 \\
\hline $\mathrm{Na}$ & $\left(\mathrm{mg} \mathrm{l}^{-1}\right)$ & $<0.1$ & $<0.1$ & 0.2 \\
\hline $\mathrm{SO}_{4}$ & $\left(\mathrm{mg} \mathrm{l}^{-1}\right)$ & 0.67 & 0.46 & 1.7 \\
\hline $\mathrm{N}\left(\mathrm{NH}_{3}\right)$ & $\left(\mathrm{mg} \mathrm{l}^{-1}\right)$ & 0.04 & 0.04 & 0.04 \\
\hline $\mathrm{N}\left(\mathrm{NO}_{3}\right)$ & $\left(\mathrm{mg} \mathrm{l}^{-1}\right)$ & 0.12 & 0.16 & 0.18 \\
\hline \multicolumn{2}{|c|}{ Specific conductivity $\left(\mu \mathrm{S} \mathrm{cm}^{-1}\right)$} & 4.8 & 7.4 & 12.0 \\
\hline \multicolumn{2}{|c|}{ Total volume $(\mathrm{ml})$} & 725 & 500 & 990 \\
\hline \multicolumn{2}{|c|}{$\mathrm{pH}$ (electrode) } & 5.12 & 4.81 & 7.40 \\
\hline \multicolumn{2}{|c|}{ pH (Gran's plot) } & 5.02 & 4.76 & nil \\
\hline
\end{tabular}

TABLE II. SNOWMELT WATER CHEMISTRY AND SULPHATE DEPOSITION ONTO THE LAKE AND LAND SURFACE OF THE SITE AT HAULTAIN LAKE FOR THE MARCH 1983 STUDY

\begin{tabular}{lccccccc}
\hline Surface & $\begin{array}{c}\text { Snow } \\
\text { depth } \\
(\mathrm{cm})\end{array}$ & $\begin{array}{c}\text { Meltwater Equivalent } \\
(\mathrm{ml})\end{array}$ & $\begin{array}{c}\text { Eater depth } \\
(\mathrm{cm})\end{array}$ & $\begin{array}{c}\text { Conductivity } \\
\left(\mu \mathrm{S} \mathrm{cm}^{-1}\right)\end{array}$ & $\begin{array}{c}\mathrm{pH} \\
(\mathrm{range})\end{array}$ & $\begin{array}{c}\text { Sulphate } \\
\text { concentration } \\
\left(\mathrm{mg} 1^{-1}\right)\end{array}$ & $\begin{array}{c}\text { Sulphate } \\
\text { deposition } \\
\left(\mathrm{mg} \mathrm{m}^{-2}\right)\end{array}$ \\
\hline Lake & $28 \pm 4$ & $529 \pm 62$ & $6.5 \pm 0.7$ & $6.9 \pm 0.6$ & $4.81-6.75$ & $0.47 \pm 0.06$ & 30.6 \\
Land & $46 \pm 10$ & $858 \pm 132$ & $10.6 \pm 1.6$ & $6.7 \pm 0.4$ & $4.43-4.93$ & $0.47 \pm 0.09$ & 49.8 \\
\hline
\end{tabular}

TABLE III. COMPARISON OF SNOWMELT WATER CHEMISTRY PARAMETERS FOR HAULTAIN LAKE BETWEEN 1982 AND 1983

\begin{tabular}{lccccc}
\hline Year & $\begin{array}{c}\mathrm{SO}_{4}^{2-} \\
\left(\mathrm{mg} \mathrm{l}^{-1}\right)\end{array}$ & $\begin{array}{c}\mathrm{NO}_{3}^{-}-\mathrm{N} \\
\left(\mathrm{mg} \mathrm{1} 1^{-1}\right)\end{array}$ & $\begin{array}{c}\text { Conductivity } \\
\left(\mu \mathrm{S} \mathrm{cm}^{-1}\right)\end{array}$ & Snow density & $\begin{array}{c}\mathrm{pH} \\
(\mathrm{range})\end{array}$ \\
\hline 1983 & $0.47 \pm 0.06$ & $0.15 \pm 0.01$ & $6.9 \pm 0.6$ & $0.23 \pm 0.04$ & $4.81-6.75$ \\
1982 & $0.43 \pm 0.07$ & $0.09 \pm 0.01$ & $5.7 \pm 1.8$ & $0.24 \pm 0.03$ & $5.04-6.78$ \\
\hline
\end{tabular}


TABLE IV. CONCENTRATIONS OF TRACE ELEMENTS (in $10^{-9} \mathrm{~g} \mathrm{~g}^{-1}$ ) IN THE SNOW CORES AT VARIOUS DISTANCES FROM THE SMELTER AT FLIN FLON ALONG A TRANSECT TO THE NORTH-WEST

\begin{tabular}{lcccccc}
\hline $\begin{array}{c}\text { Distance } \\
(\mathrm{km})\end{array}$ & $\mathrm{SO}_{4}$ & $\mathrm{Fe}$ & $\mathrm{Mn}$ & $\mathrm{As}$ & $\mathrm{Zn}$ & $\mathrm{Pb}$ \\
\hline 5 & 1700 & 110 & 2 & 36.0 & 720 & 84 \\
15 & 1400 & 400 & 5 & 23.0 & 400 & 35 \\
30 & 750 & 60 & 2 & 2.6 & 70 & 9 \\
60 & 970 & 170 & 8 & 2.0 & 29 & 4 \\
100 & 890 & 22 & 10 & 1.1 & 13 & 5 \\
300 & 470 & 24 & 1 & $<0.5$ & 6 & 4 \\
600 & 490 & 24 & $<0.5$ & 5 & $<2$ \\
\hline
\end{tabular}

The regional distribution of sulphate concentration in the melted snow cores is shown in Figure 3. In the vast area of the Precambrian Shield the sulphate distribution is reasonably uniform. The sharp transition in concentration occurs when the area south of the treeline is encountered. This area is mostly farm land. Snow drifts and mixes with the soil dust quite extensively. Consequently most snow cores consist of well-mixed constituents of soil dust. In the forested areas north of the treeline, however, the soils are much less exposed to wind erosion. The intrusion of sulphate into the south-east corner is likely from the metal smelters at Flin Flon, in combination with natural influences. The natural contribution is clearly defined because increases in sulphate in this region of the study area are paralleled by increases in alkaline earth metal concentrations (Table I). Welsh Lake which is located in the higher sulphate zone of the southeast also has much higher levels of calcium and magnesium than does the Haultain Lake area. The intrusion into the north-west corner is probably a natural impact of soil dust from the Athabasca River valley. The Athabasca River valley is approximately $50 \mathrm{~km}$ adjacent to the Precambrian Shield area in this part of Canada and is least sensitive to acid deposition.

The concentration of various constituents across the Precambrian Shield is shown in Table I. The lakes represented by the Tazin and Haultain site are considered typical of central shield areas. While Welsh Lake is located on the shield, its more southerly location shows higher deposition for every constituent with the exception of hydrogen ions. Acidity values in the central shield range from 20 to $40 \mu^{-1}$. The amount of acidity decreases rapidly at Welsh Lake. This site is located 50 $\mathrm{km}$ west of the smelter source at Flin Flon. It should be noted that the concentration of nitrogen compounds such as ammonia and nitrate are exceedingly low in this study area.

The bicarbonate concentration at lakes located in the central portion of the shield is near detection limits. However as the southern fringe areas of the shield areas are entered, the bicarbonates increase in concentration. Elements such as $\mathrm{Ca}, \mathrm{Mg}, \mathrm{K}$ and $\mathrm{Na}$ are also seen to increase in concentration as the southerly area is approached. The $\mathrm{pH}$ values determined by electrode and titration procedures were in good agreement provided there was sufficient hydrogen ion present $\left(>10 \mu\right.$ eq $\left.\mathrm{I}^{-1}\right)$. However as the hydrogen ion content was lowered the titration methods were of limited value, for example, at the Welsh Lake site.

Table II is a summary of observations of land and lake depositions at the Haultain Lake site which is located near the centre of Saskatchewan's Precambrian Shield. Each observation represents the mean and standard error of 16 separate observations taken from each surface. The lake basin is typical of the freshwater ecosystems that are highly sensitive to acid deposition. However the concentration of sulphate in the meltwater remains similar.

A comparison of concentrations of sulphate, nitrate, hydrogen ion, etc., at Haultain Lake is shown in Table III for the two winter seasons where data are available. While increases in concentration of the order of $10 \%$ are observed, the total sulphate and nitrate concentrations are not significantly different within the limits of variability.

The variation in concentrations of sulphate and metals in snow with distance from the Flin Flon smelter are shown in Table IV. Most metal concentrations are quite low on the shield, of ten approaching values that are typical of remote regions. The concentration of many of the anthropogenic metals, such as $\mathrm{As}, \mathrm{Zn}$, and $\mathrm{Pb}$, is influenced by the smelter for a distance of at least $100 \mathrm{~km}$. The gradient of arsenic is particularly evident. It is seen that elements that are more crustal in origin ( $\mathrm{Fe}$ and $\mathrm{Mn}$ ) have a more uniform distribution along the transect.

\section{CONCLUSIONS}

The regional distribution of sulphate in the meltwater of the snow from northern Saskatchewan is low and relatively uniform. The influence of open prairie land on the concentration of sulphate in the snow suggests that the soil is contributing substantially to this ion in the snowpack. However, in areas covered by trees remote from prairie lands deposition is likely to come directly from the atmosphere. The total deposition of sulphate to the snow of the shield during winter is well below $100 \mathrm{mg} \mathrm{m}^{-2}$, and the $\mathrm{pH}$ of the snow is $\sim 4.9$. Recent evidence suggests that organic acids may influence to some extent the acidity of precipitation in remote areas (Keene and others 1983).

\section{ACKNOWLEDGEMENTS}

Major funding for this research was provided by Saskatchewan Environment. I would like to thank Mr L J Lechner of Saskatchewan Environment for his interest in my group. In addition, special acknowledgements are due to several employees of the Saskatchewan Research Council. They are $\mathrm{Mr}$ Bob MacPherson, who was the aircraft pilot, and Mr James Ross, who was the laboratory assistant in this project. 


\section{REFERENCES}

Barrie L A 1980 The fate of particulate emissions from an isolated plant in the oil sands area of western Canada. Annals of the New York Academy of Sciences 338: 434-452

Canada. Minister of Supply and Services 1981 Still waters. Report of the Sub-Committee on Acid Rain of the Standing Committee on Fisheries and Forestry. Ottawa, Minister of Supply and Services

Elgmork K, Hagen A, Langeland A 1973 Polluted snow in southern Norway during the winters 1968-1971. Environmental Pollution 4(1): 41-52

Gran G 1952 Determination of equivalence in potentiometric titrations. Analyst 77: 661-671

Hopkinson R F, Dublin J 1981 Meteorological controls on air pollutants in a selected region of western Canada. Proceedings. Air pollution sessions. Canadian Meteorological and Oceanographic Society, 15th Annual Congress, Saskatoon, Saskatchewan May 27-29, 1981: 87-98

Johannessen M, Henriksen A 1978 Chemistry of snow meltwater: changes in concentration during melting. Water Resources Research 14(4): 615-619

Keene W C, Galloway J N, Holden J D Jr 1983 Measurement of weak organic acidity in precipitation from remote areas of the world. Journal of Geophysical Research 88(C9): 5122-5130

Shewchuk S R 1979 A background study of potential sulphur stresses in west central Saskatchewan. Saskatchewan Research Council. Report P79-6

Shewchuk S R 1982 An acid deposition perspective of northeastern Alberta and northern Saskatchewan. Water. Air and Soil Pollution 18: 413-419

Webber H J, Warne G A 1979 Sulphur emissions - Alberto energy industries. Presented to PNWIS - APCA annual meeting 7-9 November 1979, Edmonton, Alberta. Edmonton, Alberta, Alberta Environment. Research Secretariat 